\title{
PENENTUAN FORMULASI OPTIMUM PEMBUATAN COOKIES DARI BEKATUL PADI PANDANWANGI DENGAN PENAMBAHAN TEPUNG TERIGU MENGGUNAKAN METODE RSM (Response Surface Method)
}

\author{
Oleh : \\ Riza Trihaditia, ST. MT \\ Melissa Syamsiah, S.Pd, M.Si \\ Aliya Awaliyah, SP
}

\begin{abstract}
Abstrak
Bekatul merupakan hasil limbah dari padi yang berpotensi untuk dapat dimanfaatkan menjadi produk pangan. Maka dari itu melihat hal tersebut kiranya dapat dibuat sebuah produk yang praktis, mudah dikonsumsi dan banyak diminati dalam bentuk biskuit yang berasal dari proses penambahan bekatul yang dicampur dengan tepung terigu, telur, gula dan margarine. Penelitian ini difokuskan untuk mengetahui pengaruh formulasi bekatul dengan tepung terigu terhadap mutu organoleptik cookies bekatul serta mengetahui respon optimum uji organoleptik cookies bekatul sebagai produk diversifikasi pangan. Data diolah menggunakan metode RSM (Response Surface Method) dengan melibatkan 25 panelis biasa dan 1 orang panelis ahli dengan parameter uji yang dilakukan yaitu meliputi tekstur, warna, aroma dan rasa. Masing-masing panelis diberikan 4 sampel berbeda pada setiap formulasinya. Karakteristik untuk warna dan aroma yang diminati oleh panelis yaitu sampel F4 (Bekatul $40 \%+$ Tepung terigu 60\%) dengan nilai optimasi warna 1 sedangkan nilai optimasi aroma 3. Sementara untuk parameter sampel tekstur dan rasa yang diminati oleh panelis adalah sampel F2 (Bekatul 60\% + Tepung terigu 40\%) dengan nilai optimasi yaitu 1 .
\end{abstract}

Kata kunci : Bekatul, limbah, Cookies, metode RSM.

\begin{abstract}
Bran is the result of waste from rice that has the potential to be used as food product. Therefore looking at it can be made a product that is practical, easy to consume and much in demand in the form of biscuits derived from the process of adding bran, which is mixed with flour, eggs, sugar and margarine. This research is focused to know the influence of bran formulation with wheat flour to organoleptic quality of bran cookies and to know the optimum test of organoleptic test of bran cookies as food diversification product. The data was processed using RSM (Response Surface Method) method by invloving 25 regular panelists and 1 expert panel with test parameters which were done that were covering texture, color, flavor, and taste. Each panelist is given 4 different samples in each formulation. Characteristic for color and aroma of interest by panelist that is sample of F4 (Bekatul 40\% + Flour 60\%) with color optimization value 1 while the value of aroma optimization 3. While for sample texture and taste parameters by panelist is sample F2 (Bekatul $60 \%+$ Flour $40 \%$ ) with optimization value that is 1 .
\end{abstract}

Keywords : Bran, Waste, Cookies, RSM.

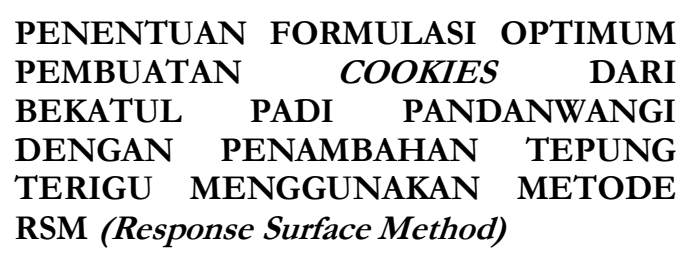

RIZA TRIHADITIA, MELISSA SYAMSIAH dan ALIYA AWALIYAH 


\section{PENDAHULUAN}

Salah satu negara yang termasuk jajaran negara agraris di dunia adalah Indonesia. Terutama pada sektor pertanian yaitu padi sebagai kebutuhan pangan. Indonesia dalam setiap tahunnya mampu menghasilkan padi sebesar 47 juta ton. Hal ini, setara bahwa produksi beras mencapai 32 juta ton dalam pertahun (Dio, 2010).

Produksi samping sektor pertanian yang tidak kalah melimpahnya di Indonesia adalah bekatul. Bekatul merupakan salah satu hasil proses penggilingan padi selain beras. Meskipun bekatul di Indonesia tersedia dalam jumlah melimpah, pemanfaatannya hanya sebatas pakan ternak dan unggas saja.

Bekatul mengandung karbohidrat, protein, mineral, lemak, multi vitamin $\mathrm{B}$ (B1, B2, B3, B5, B6, dan B15), komponen-komponen bioaktif termasuk nitrilosid (zat yang sekarang sedang diperbincangkan sebagai zat antikanker), dan dietary fiber (serat pencernaan). Salah satu kandungan tertinggi di dalam Salah satu kandungan yang tertinggi di dalam bekatul adalah vitamin B15 berfungsi untuk mengoptimalkan kerj organ tubuh manusia. Selain daripada itu, kandungan nilai gizi pada bekatul dapat mengalahkan gizi beras putih.

Selama ini bekatul dipandang sebagai limbah karena sebagai salah satu proses pengolahan gabah menjadi beras dan kurang bermanfaat atau bermutu rendah dan memiliki nilai ekonimis yang rendah. Bekatul merupakan sisa penumbukan atau penggilingan padi. Namun sejak dulu, bekatul dikenal oleh masyarakat hanya sebagai bahan pakan ternak. Sehingga bekatul yang berlimpah tersebut perlu adanya diversifikasi pangan agar semakin bermanfaat dan memiliki daya jual yang sangat tinggi yaitu digunakan sebagai bahan tambahan atau campauran untuk produk makanan.
Penambahan bekatul pada proses pembuatan produk merupakan bertujuan untuk meningkatkan kandungan gizi terutama protein dan akan memiliki nilai tambah bagi terhadap produk tersebut. Selain daripada itu, dengan adanya penambahan bekatul ini dapat meningkatkan kualitas karena terdapat kandungan bsine yang cukup tinggi dan meningkatkan nilai gizi. Sedangkan jika proses pembuatan produk rendah merupakan adanya asam amino pembatas bsine.

Melihat hal-hal di atas, maka bekatul dapat dibuat sebagai produk yang praktis, mudah dikonsumsi dan banyak diminati yaitu dibentuk biskuit yang dicampur dengan tepung terigu, margarin, gula dan telur.

Biskuit adalah salah satu jenis kue kering yang memiliki rasa manis, berbentuk kecil dan diperoleh dari proses pengeringan menggunakan oven. Bahan dasar yang digunakan yaitu dasar tepung terigu, margarin, kuning telur dan gula halus. Tujuan dari penelitian ini adalah membuat inovasi dengan menciptakan biskuit dengan substitusi bekatul, menganalisis pengaruh penambahan bekatul terhadap kadar protein dan sifat organoleptik biskuit dengan variabel warna, aroma, tekstur dan rasa.

Berdasarkan paparan yang dikemukakan di atas maka rumusan masalah sebagai berikut ::

1. Bagaimana pengaruh formulasi bekatul tepung terigu terhadap mutu organoleptik cookies bekatul.

2. Bagaimana respon optimum dari uji organoleptik cookies bekatul sebagai produk diversifikasi pangan padi Pandanwangi.

Berdasarkan rumusan masalah yang dipaparkan, maka penelitian ini bertujuan sebagai berikut:

1. Mengetahui pengaruh formulasi bekatul tepung terigu terhadap mutu organoleptik cookies bekatul.

\author{
PENENTUAN FORMULASI OPTIMUM \\ PEMBUATAN COOKIES DARI \\ BEKATUL PADI PANDANWANGI \\ DENGAN PENAMBAHAN TEPUNG \\ TERIGU MENGGUNAKAN METODE \\ RSM (Response Surface Method)
}

RIZA TRIHADITIA, MELISSA SYAMSIAH dan ALIYA AWALIYAH 
2. Mengetahui respon optimum uji organoleptik cookies bekatul sebagai produk diversifikasi pangan padi Pandanwangi.

Dengan mengetahui dan mendapatkan optimalisasi cookies bekatul, maka penelitian ini diharapkan dapat :

a. Menambah ilmu tentang manfaat bekatul sebagai bahan sisa yang tidak dimanfaatkan.

b. Memberikan tambahan referensi masyarakat dan pelaku usaha yang ingin bergerak dibidang pengolahan produk pangan dengan bahan baku bekatul.

Berdasarkan kerangka pemikiran di atas dapat diambil hipotesis sebagai berikut :

1. Penambahan bekatul sebagai bahan utama pada cookies berpengaruh terhadap aroma, tekstur, rasa dan warna cookies.

\section{METODE PENELITIAN}

Penelitian ini dilakukan di Laboratorium Pangan Fakultas Sains Terapan Universitas Suryakancana Cianjur dari bulan Februari - April 2018.

Dalam pelaksanaan percobaan ini penulis menggunakan beberapa alat serta bahan yang diperlukan. Alat yang digunakan yaitu mixer, loyang, ayakan, timbangan, oven.

Tabel 1 Rancangan Eksperimen Cookies Bekatul

\begin{tabular}{cccc}
\hline Formulasi & Formula Bekatul $(\%)$ & Tepung Terigu $(\%)$ & Total \\
\hline F1 & 70 & 30 & 100 \\
F2 & 60 & 40 & 100 \\
F3 & 50 & 50 & 100 \\
F4 & 40 & 60 & 100 \\
\hline
\end{tabular}

Data diperoleh menggunakan uji organoleptik untuk mengetahui penilaian konsumen terhadap mutu cookies bekatul dengan variabel tekstur, warna, aroma dan rasa dengan panelis sebanyak 25 orang panelis biasa dan 1 orang panelis ahli. Bahan uji akan diolah langsung di lokasi

\footnotetext{
PENENTUAN FORMULASI OPTIMUM

PEMBUATAN COOKIES DARI

BEKATUL PADI PANDANWANGI

DENGAN PENAMBAHAN TEPUNG

TERIGU MENGGUNAKAN METODE

RSM (Response Surface Method)
}

Sedangkan bahan yang digunakan untuk membuat cookies bekatul yaitu bekatul, telur, mentega, gula halus, dan tepung.

Penelitian ini termasuk penelitian eksperimental untuk menguji formulasi antara bekatul dengan tepung terigu yang diolah menjadi cookies bekatul. Parameter uji yang dilakukan adalah meliputi tekstur, warna, aroma dan rasa, dimana akan melibatkan 25 orang panelis dan 1 panelis ahli.

\section{Proses Pembuatan}

Berdasarkan penelitian ini, proses pembuatan cookies bekatul adalah sebagai berikut :

1. Mentega, gula halus, dan 2 butir kuning telur dikocok merata menggunakan mixer.

2. Tambahkan tepung terigu yang sudah disangrai terlebih dahulu, bekatul halus yang sudah disangrai terlebih dahulu dan vanilla bubuk.

3. Adonan dibentuk bulat, kemudian letakan diatas loyang lalu beri jarak.

4. Panggang dengan suhu $60^{\circ} \mathrm{C}$ selama 20 menit. Cookies bekatul siap dikonsumsi.

\section{Rancangan Eksperimen}

Dalam penelitian ini terdapat 4 perlakuan, diantaranya dijelaskan pada

pengujian panelis agar tekstur dan rasa setelah diolah masih terjaga.

Penelitian ini termasuk penelitian eksperimental dengan menggunakan Metode RSM (Response Surface Method) yaitu dengan 25 orang panelis biasa dan 1

RIZA TRIHADITIA, MELISSA SYAMSIAH dan ALIYA AWALIYAH 
orang panelis ahli yang setiap masingmasing akan mendapatkan 4 sampel.

\section{Variabel Penelitian}

Menurut Depkes RI (2000), pengujian organoleptik melalui pendeskripsian bentuk, warna, bau dan rasa dengan menggunakan panca indra, bertujuan untuk pengenalan awal yang sederhana dan subjektif mungkin. Sedangkan variabel penelitian dalam hal ini adalah warna, aroma, rasa serta teksturnya. Menurut kartika (1988) dalam Trihaditia (2015), Tekstur merupakan sensasi tekanan yang dapat diamati dengan mulut (pada waktu digigit, dikunyah dan ditelan) ataupun perabaan dengan jari.Macam-macam penginderaan tekstur tersebut antara lain meliputi kebasahan (juiciness), kering, keras, halus, kasar dan berminyak (Soekarto, 1985 dalam Trihaditia, 2015).

Menurut Kartika (1988) dalam Trihaditia (2015) bau atau aroma dapat didefinisikan sebagai sesuatu yang dapat diamati dengan indra pembau. Pengamatan terhadap aroma sensorik berdasarkan sensasi bau atau aroma ketika dicium dengan indra pembau. Sedangkan rasa adalah tanggapan dengan adanya rangsangan kimiawi yang sampai di indra pengecap lidah. Jenis rasa dasar yang khusus yaitu manis, asin, asam dan pahit. Indra pengecap akan mudah mengenal rasa-rasa dasar hanya bagi pengkonsumsi tinggi.

Variabel selanjutnya adalah warna cookies setelah matang, warna biasanya tanda kemasakan atau kerusakan pada makanan, seperti perlakuan penyimpanan yang memungkinkan adanya perubahan warna, meskipun makanan terlihat lezat, tetapi penampilan tidak menarik waktu disajikan maka akan mengakibatkan selera orang yang akan memakannya menjadi hilang (Rejeki, 2012).

Pengujian mutu organoleptik ini dilakukan dengan metode Hedonic Test menurut Watts (1993), yang ditransformasikan kedalam skala numerik

PENENTUAN FORMULASI OPTIMUM PEMBUATAN COOKIES DARI BEKATUL PADI PANDANWANGI DENGAN PENAMBAHAN TEPUNG TERIGU MENGGUNAKAN METODE RSM (Response Surface Method) menurut Preference test (uji kesukaan) terhadap warna, aroma, rasa dan tingkat kepekatan.

\section{Analisis Data}

Data uji mutu organoleptik akan dianalisis kemudian akan diketahui perlakuan yang optimal dengan menggunakan RSM (Response Surface Method).Menurut Trihaditia (2015), metode psermukaan respon (RSM) merupakan suatu strategi percobaan yang berguna jika respon dipengaruhi beberapa faktor dan tujuan percobaan adalah untuk mencari respon optimum dengan cara mencari tempuhan titik tengah dan tempuhan lengan bintang (star arm runs).

Trihaditia (2015) menambahkan, metode permukaan respon (RSM) merupakan suatu strategi percobaan yang berguna jika respon dipengaruhi beberapa faktor dan tujuan percobaan adalah untuk mencari respon optimum. RSM mencakup masalah : pemilihan rancangan percobaan yang cocok untuk optimasi dan metode penelusuran ruang faktor untuk mencapai daerah optimum dengan cepat.

Penggunaan metode ini berfungsi untuk mengembangkan, meningkatkan, dan mengoptimasi proses penentuan formulasi optimum. Penerapannya sangat penting terutama di bidang rancangan, pengembangan dan perumusan produk baru, serta pada peningkatan rancangan produk yang sudah ada (Trihaditia, 2015).

Metode yaang digunakan yaitu statistika untuk melihat hubungan antara satu atau lebih variabel perlakuan dan metode permukaan respon merupakan suatu himpunan metode-metode matematika yang dilakukan secara berbentuk kuantitatif dengan sebuah variabel respon yang bertujuan untuk mengoptimalkan respon tersebut dalam suatu percobaan (Montgomery, 2009).

\section{HASIL DAN PEMBAHASAN}

Hasil dari penelitian ini akan menjelaskan mengenai bagaimana bekatul

RIZA TRIHADITIA, MELISSA SYAMSIAH dan ALIYA AWALIYAH 
padi Pandanwangi hasil dari penyosohan yang diolah menjadi cookies berbahan dasar bekatul padi Pandanwangi dalam setiap parameter. Hasil penelitian ini berupa penentuan optimasi karakteristik organoleptik dan sampel terbaik dari cookies bekatul yang dinilai dari warna, aroma, rasa dan tekstur.

Sifat indrawi berfungsi sebagai penilaian bahan pangan untuk menentukan diterima atau tidak suatu produk tersebut. Salah satu indikator dalam menentukan diterima atau tidaknya suatu produk ialah sensasi yang diterima meliputi warna, aroma, rasa, dan tekstur. Penentuan akhir dari uji indrawi yang mengarah pada diterima dan tidaknya suatu produk yaitu dengan melibatkan indra pengecap dalam hal kepekaan rasa. Sejalan dengan apa yang dilakukan oleh
Wahyuningtias (2010), bahwa rasa asin terdapat di ujung dan pinggir lidah, rasa asam di pinggir lidah, rasa pahit di bagian belakang lidah dan rasa manis dapat dengan mudah dirasakan di ujung lidah. Setelah melalui tahapan proses pembuatan cookies selanjutnya dilakukan pengujian tingkat kesukaan (bedonic test) para panelis untuk mengetahui tingkat optimalisasi karakteristik organoleptik cookies berbasis bekatul Pandanwangi yang dikombinasikan dengan tepung terigu dengan variabel warna, aroma, rasa dan tekstur.

\section{A. Warna}

Melakukan perhitungan Central Composite Design dan didapatkan grafik hasil sebagai berikut : Perhitungan Central Composite Design didapatkan hasil :

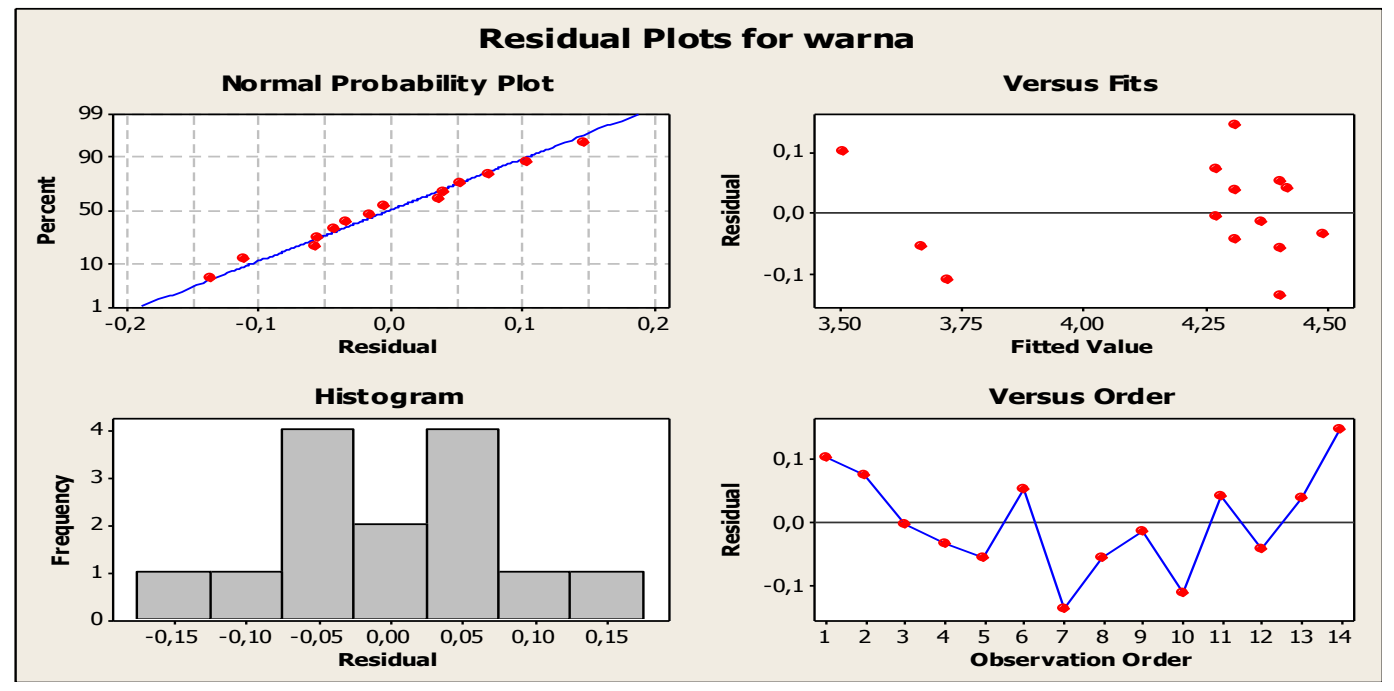

Gambar 1. Grafik Perhitungan ANOVA dari Parameter Warna

Berdasarkan pada gambar 1 dapat diketahui bahwa sebaran data untuk warna tersebar rata, serta mempunyai normal probability yang baik, dimana titik-titik data tersebut mendekati ke garis normal probability. Dikarenakan data tersebut normal dan sebarannya merata, untuk itu data-data tersebut dapat dilakukan perhitungan selanjutnya.
PENENTUAN FORMULASI OPTIMUM

PEMBUATAN COOKIES DARI

BEKATUL PADI PANDANWANGI

DENGAN PENAMBAHAN TEPUNG

TERIGU MENGGUNAKAN METODE

RSM (Response Surface Method)
RIZA TRIHADITIA, MELISSA SYAMSIAH dan ALIYA AWALIYAH 


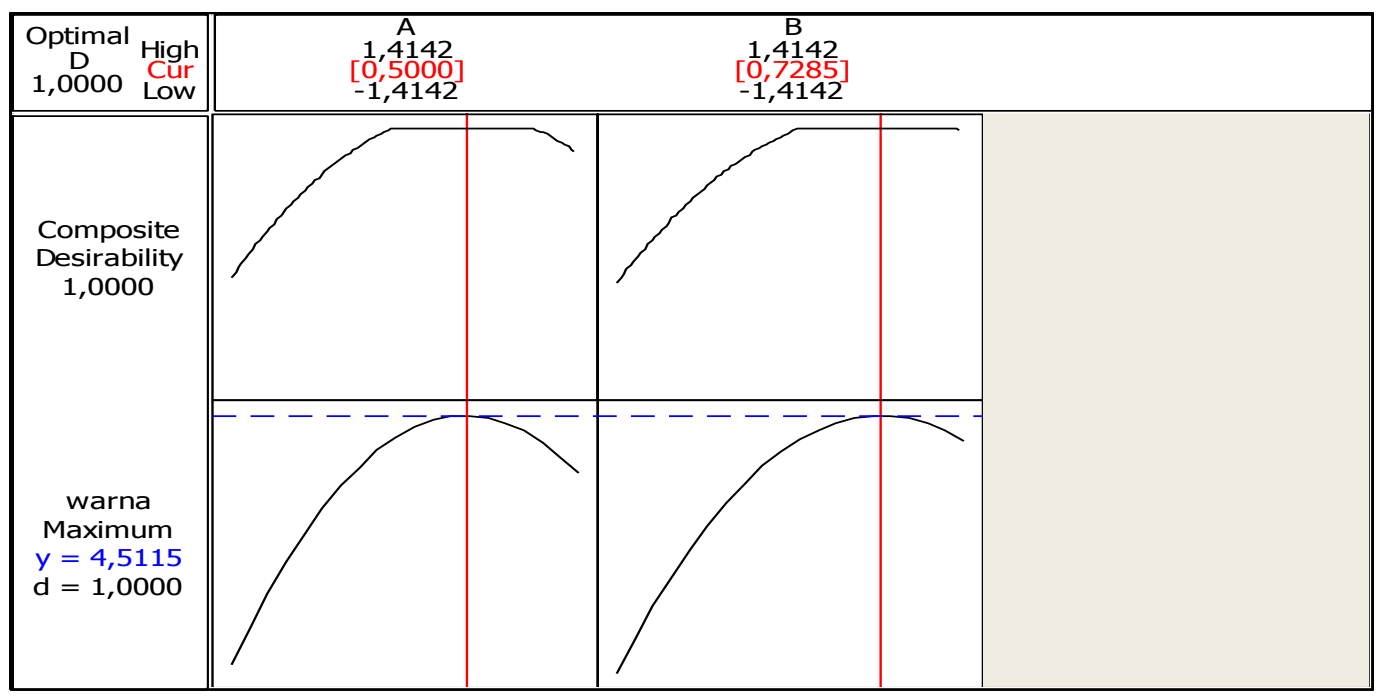

Gambar 2. Nilai Optimasi dari Parameter Warna

Pada gambar 2 perhitungan untuk optimasi akan didapatkan bahwa nilai warna akan optimal pada nilai 4,5115. Dimana akan membentuk suatu parabola yang terbuka ke bawah dan mencirikan bahwa nilai warna tersebut mempunyai nilai optimal. Nilai fungsi desirability menunjukan skala nilai 1.00 dimana menurut Deringer dan Suich (2002) dalam
Sunaryo (2008), skala $1.00-0.80$ menunjukan angka sangat baik artinya parameter warna ideal dan bisa diterima oleh panelis. Setelah nilai optimasi dari parameter warna diketahui maka akan ditentukan daerah optimasi oleh grafik secara contour dan surface, lalu didapatkan hasil sebagai berikut:

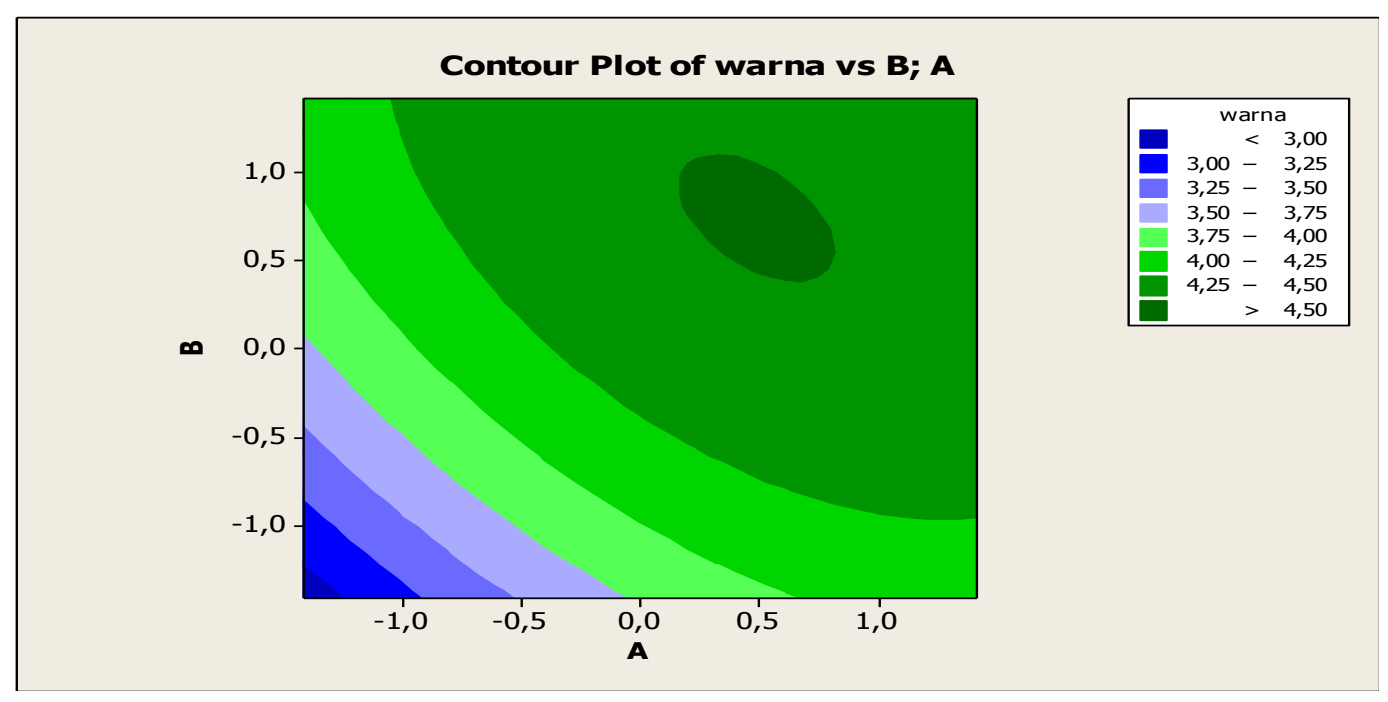

Gambar 3. Contour Wilayah Optimasi dari Warna

Dari gambar 3 dapat diketahui bahwa batasan wilayah untuk nilai optimasi adalah diantara $3,00-4,50$.
Penentuan wilayah optimasi tersebut dapat direpresentasikan dengan bentuk 3D. Bisa dilihat pada gambar 4.

\section{PENENTUAN FORMULASI OPTIMUM PEMBUATAN COOKIES DARI BEKATUL PADI PANDANWANGI DENGAN PENAMBAHAN TEPUNG TERIGU MENGGUNAKAN METODE RSM (Response Surface Method)}

RIZA TRIHADITIA, MELISSA SYAMSIAH dan ALIYA AWALIYAH 


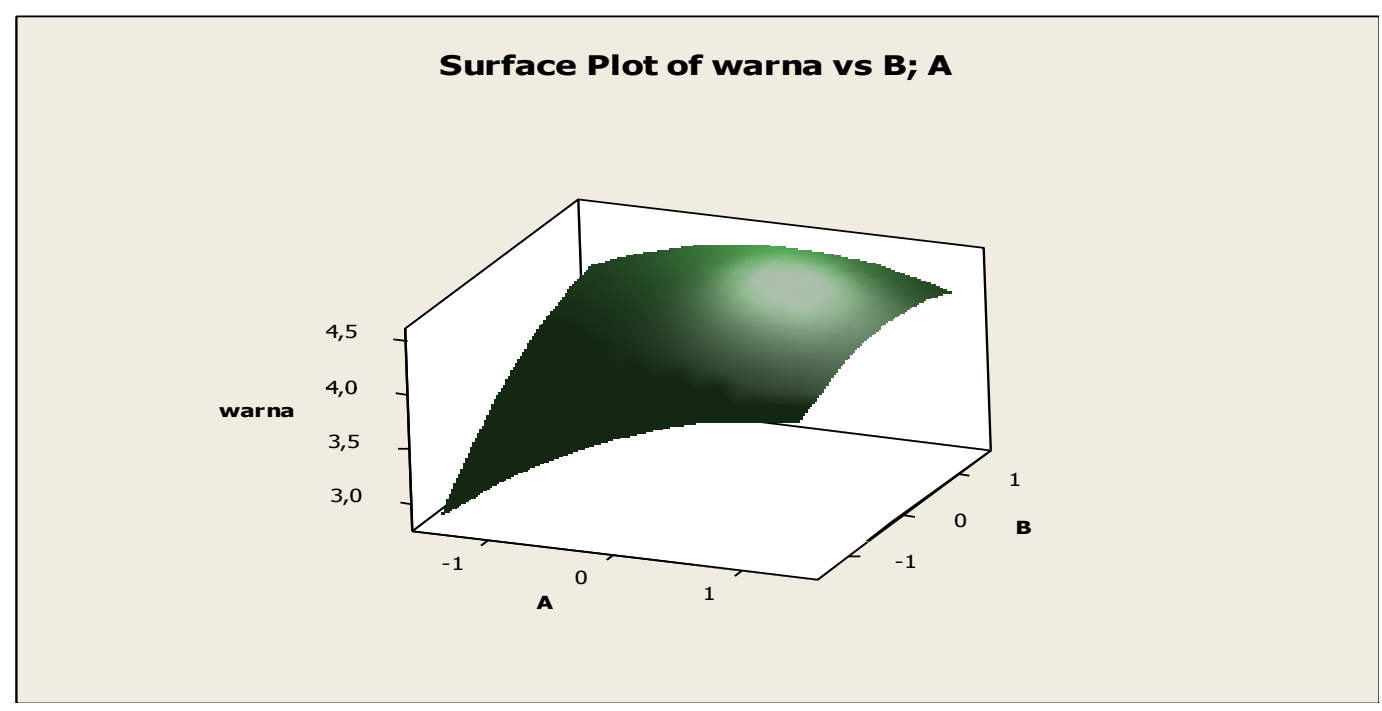

Gambar 4. Surface Plot Wilayah Optimasi dari Warna

Dari gambar 4 Surface Plot Wilayah Optimasi akan didapatkan penentuan wilayah optimasi berdasarkan nilai rata-rata sampel. Untuk batasan wilayahnya dapat dilihat pada tabel 2 . Penelitian ini didasarkan pada pengujian 4

Tabel 2 Wilayah Optimasi Rata-Rata Warna formulasi berbeda yang disajikan kepada 26 panelis. Setelah dilakukan uji organoleptik terhadap parameter warna, didapatkan hasil data penelitian yang disajikan pada tabel 2 :

\begin{tabular}{cc}
\hline Wilayah Optimasi & Rata-rata Warna \\
\hline 1 & $>4,50$ \\
2 & $4,25-4,50$ \\
3 & $4,00-4,25$ \\
4 & $3,75-4,00$ \\
5 & $3,50-3,75$ \\
6 & $3,25-3,50$ \\
7 & $3,00-3,25$ \\
8 & $<3,00$ \\
\hline
\end{tabular}

Sumber : Data primer (olahan) tahun 2018

Untuk mendapatkan nilai optimal dari berbagai jenis sampel yang digunakan, maka nilai rata-rata sampel tersebut akan dimasukan ke dalam plot wilayah optimasi,

Tabel 3 Nilai Optimasi Rata-Rata Warna

\begin{tabular}{ccc}
\hline Sampel & Rata-rata & Wilayah Optimasi \\
\hline F1 (BK 70\%: TT 30\%) & 3,61 & 5 \\
\hline F2 (BK 60\%: TT 40\%) & 4,35 & 2 \\
\hline F3 (BK 50\%: TT 50\%) & 4,27 & 2 \\
\hline F4 (BK 40\%: TT 60\%) & 4,50 & 1 \\
\hline
\end{tabular}

Sumber : Data primer (olahan) tahun 2018

*Keterangan : BK (Bekatul), TP (Tepung Terigu)

PENENTUAN FORMULASI OPTIMUM

PEMBUATAN COOKIES DARI

BEKATUL PADI PANDANWANGI

DENGAN PENAMBAHAN TEPUNG

TERIGU MENGGUNAKAN METODE

RSM (Response Surface Method) sehingga akan didapatkan nilai optimasi dari berbagai sampel tersebut dapat dilihat pada tabel 3 : 
Kemudian dari tabel 3 dapat diketahui bahwa sampel dengan F1 (BK $70 \%$ : TT 30\%) mempunyai nilai optimasi 5. F2 (BK 60\% : T'T 40\%) mempunyai nilai optimasi 2, dikarenakan rata-rata sampel tersebut berada diwilayah dengan nilai optimasi 2, F3 (BK 50\% : TT 50\%) mempunyai nilai optimasi 2, dikarenakan rata-rata sampel tersebut berada diwilayah dengan nilai optimasi 2.

Sampel terbaik untuk nilai optimasi warna adalah sampel F4 (BK 40\% : TT 60\%), dikarenakan sampel tersebut memiliki nilai optimasi 1 . Dilihat dari hasil tersebut, diduga panelis lebih senang dengan cookies yang berwarna lebih cerah. Tingkat kecerahan warna cookies tersebut dikarenakan proses pencampuran sampel ini lebih banyak didominasi oleh tepung terigu, dikarenakan bekatul pada saat setelah disangrai kemudia di oven mengalami perubahan warna yang lebih gelap.

Kandungan asam amino esensial dalam bekatul antara lain sistein, arginin, histidin dan triptofan. Jenis serat pangan terdiri atas selulosa, hemiselulosa, pektin, arabinosilan, lignin, dan $\beta$-glukan. Selain itu, bekatul juga mengandung beberapa komponen bioaktif, seperti oryzanol, asam kafeat, asam ferulat, tricine, asam kumarat, asam fitat, dan karotenoid ( $\alpha$ karoten, $\beta$-karoten, lutein, likopen) , isoform vitamin E ( $\alpha$-tokoferol, $\gamma$ tokoferol, tokotrienol), fitosterol ( $\beta$ sitosterol, stigmasterol, kampesterol) (Henderson, et al., 2012).

Menurut Yuniarrahmani (2001) bahwa suhu $130^{\circ} \mathrm{C}$ selama 10 menit stabilisasi untuk metode penyangraian bekatul. Namun, semakin lama waktu proses penyangraian akan menimbulkan bau gosong. Dalam hasil produk yang dihasilkan yaitu coklat tua, kering, dan berbau harum merupakan sebagai penilaian organoleptik terhadap produk.

Dalam proses penyangraian yang dilakukan pada suhu $130^{\circ} \mathrm{C}$ selama 10 menit dapat merubah warna dari bekatul menjadi lebih gelap atau kecoklatan. Seperti yang sudah dijelaskan oleh Fellows (1990), yang mengatakan bahwa umumnya lama pengeringan dan suhu yang tinggi meningkatkan kehilangan dan kerusakan pigmen.

$$
\text { Penyangraian menyebabkan }
$$
reaksi pencoklatan salah satunya pembentukan senyawa aroma dari hasil reaksi Maillard yang bersifat sebagai antioksidan. Reaksi Maillard adalah reaksi antara gula reduksi dan protein yang membentuk senyawa coklat melanoidin yang berkaitan dengan warna, aroma, dan aktivitas antioksidan pada pangan (Hamid, et al., 2007). Akumulasi pigmen berwarna coklat merupakan indikasi yang menunjukan terjadinya reaksi Maillard pada makanan yang mengandung protein dan karbohidrat.

Begitu pula kandungan lemak dari kuning telur dan margarin selama pengovenan atau proses pemanasan mengalami oksidasi membentuk senyawa radikal yang kemudian berkondensasi satu sama lain membentuk senyawa yang berwarna coklat (Agustini, et al., 2014).

Diduga panelis lebih menyukai cookies yang berwarna lebih cerah karena dianggap cookies berwarna lebih gelap diidentifikasikan sebagai makanan yang kurang menarik serta kurang nikmat untuk dikonsumsi.

\section{B. Aroma}

Melakukan perhitungan Central Composite Design didapatkan hasil :

\author{
PENENTUAN FORMULASI OPTIMUM \\ PEMBUATAN COOKIES DARI \\ BEKATUL PADI PANDANWANGI \\ DENGAN PENAMBAHAN TEPUNG \\ TERIGU MENGGUNAKAN METODE \\ RSM (Response Surface Method)
}

RIZA TRIHADITIA, MELISSA SYAMSIAH dan ALIYA AWALIYAH 


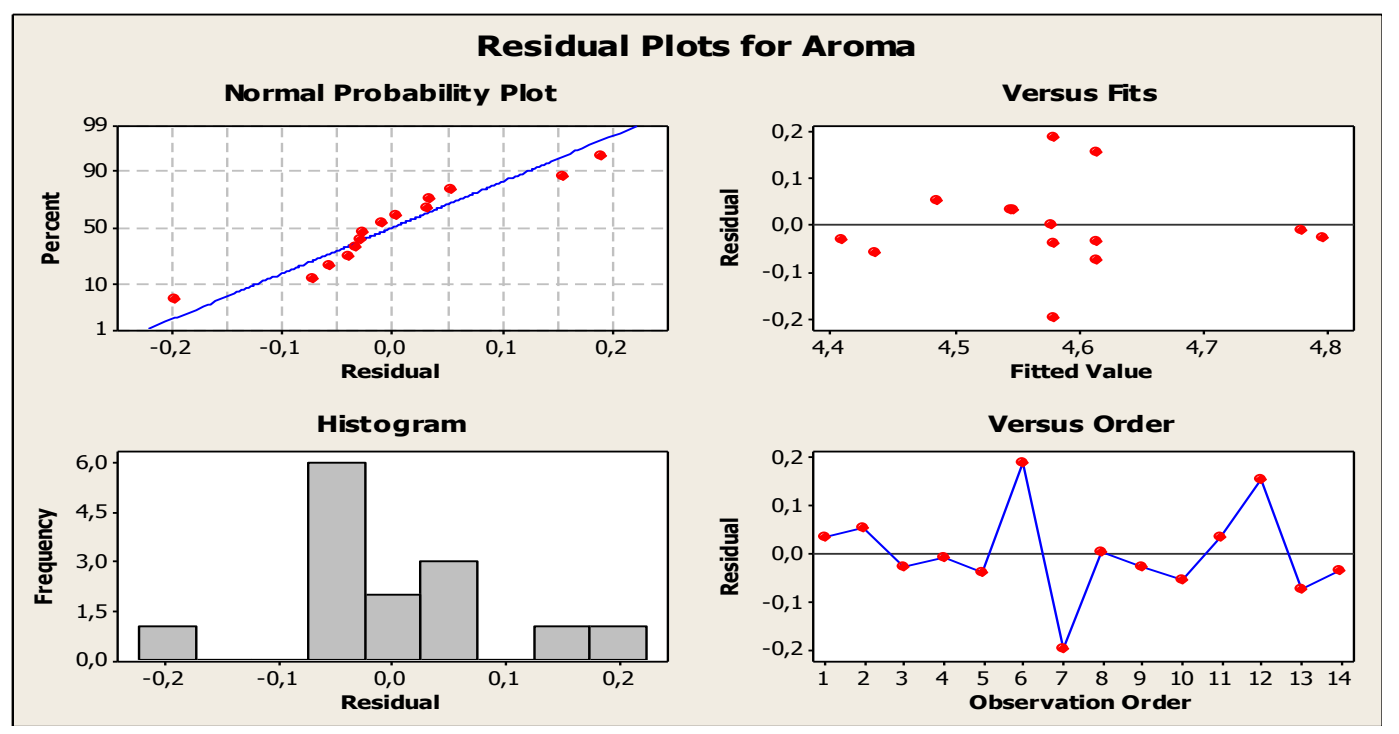

Gambar 5 Grafik Perhitungan ANOVA dari Parameter Aroma

Berdasarkan pada gambar 5 dapat diketahui bahwa sebaran data untuk aroma tersebar rata, serta mempunyai normal probability yang baik, dimana titiktitik data tersebut mendekati ke garis normal probability. Dikarenakan data tersebut normal dan sebarannya merata, untuk itu data-data tersebut dapat dilakukan perhitungan selanjutnya.

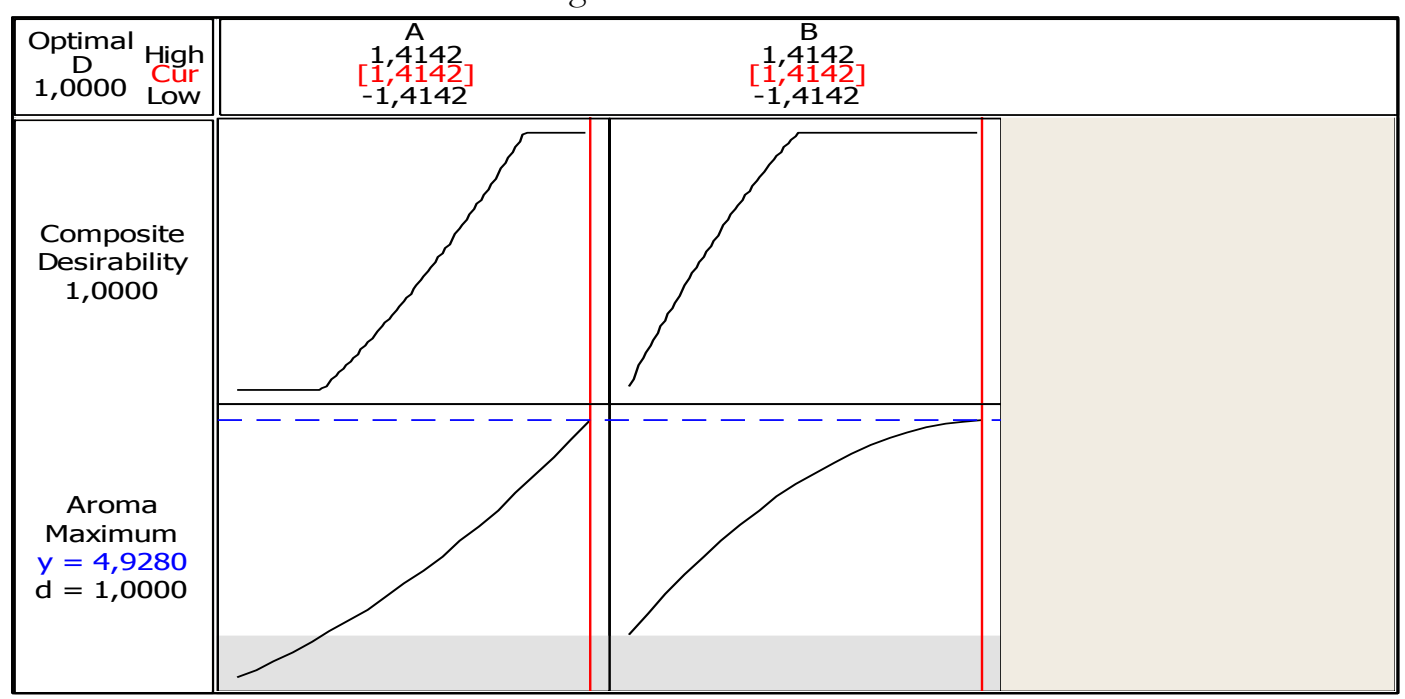

Gambar 6 Nilai Optimasi dari Parameter Aroma

Pada gambar 6 perhitungan untuk optimasi akan didapatkan bahwa nilai aroma akan optimal pada nilai 4,9280, dimana akan membentuk suatu parabola yang terbuka kebawah dan mencirikan bahwa nilai aroma tersebut mempunyai nilai optimal. Fungsi desirability menunjukan nilai 1,00 artinya nilai optimasi aroma cukup baik. Penentuan daerah optimasi dapat digunakan grafik secara Contour dan Surface, didapatkan hasil:

\section{PENENTUAN FORMULASI OPTIMUM PEMBUATAN COOKIES DARI BEKATUL PADI PANDANWANGI DENGAN PENAMBAHAN TEPUNG TERIGU MENGGUNAKAN METODE RSM (Response Surface Method)}

RIZA TRIHADITIA, MELISSA SYAMSIAH dan ALIYA AWALIYAH 

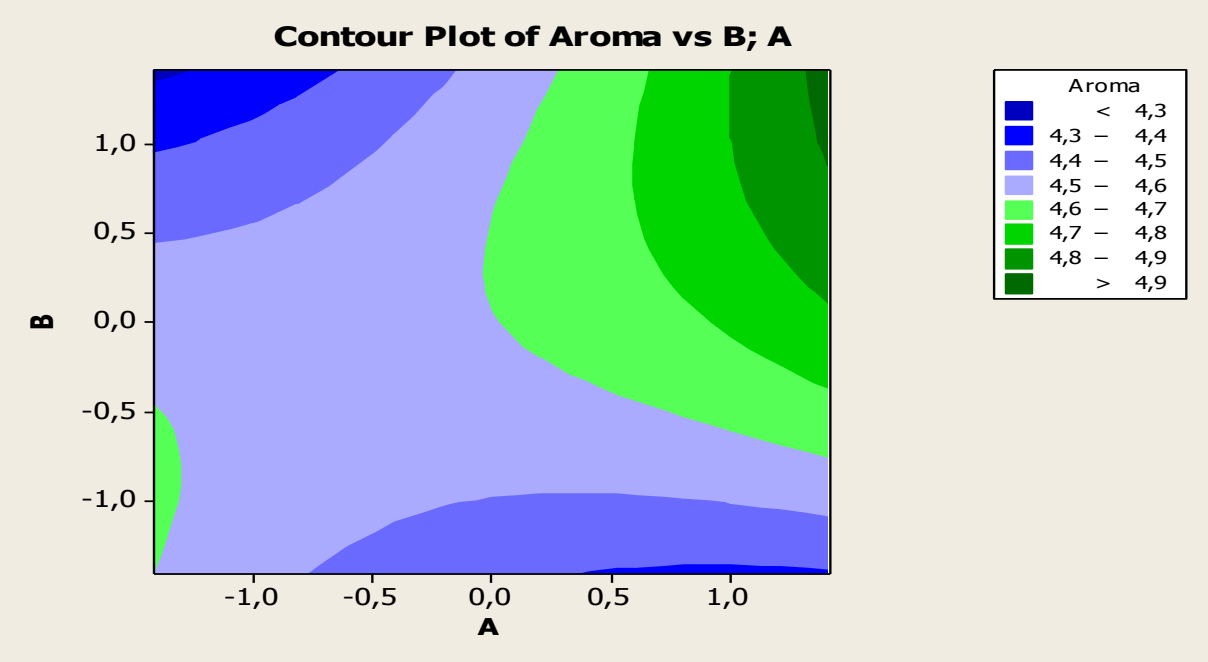

Gambar 7. Contour Wilayah Optimasi dari Aroma

Dari gambar 7 dapat diketahui bahwa batasan wilayah untuk nilai optimasi adalah 4,3 - 4,9. Untuk merepresentasikan dalam bentuk 3D bisa kita lihat pada gambar 8 .

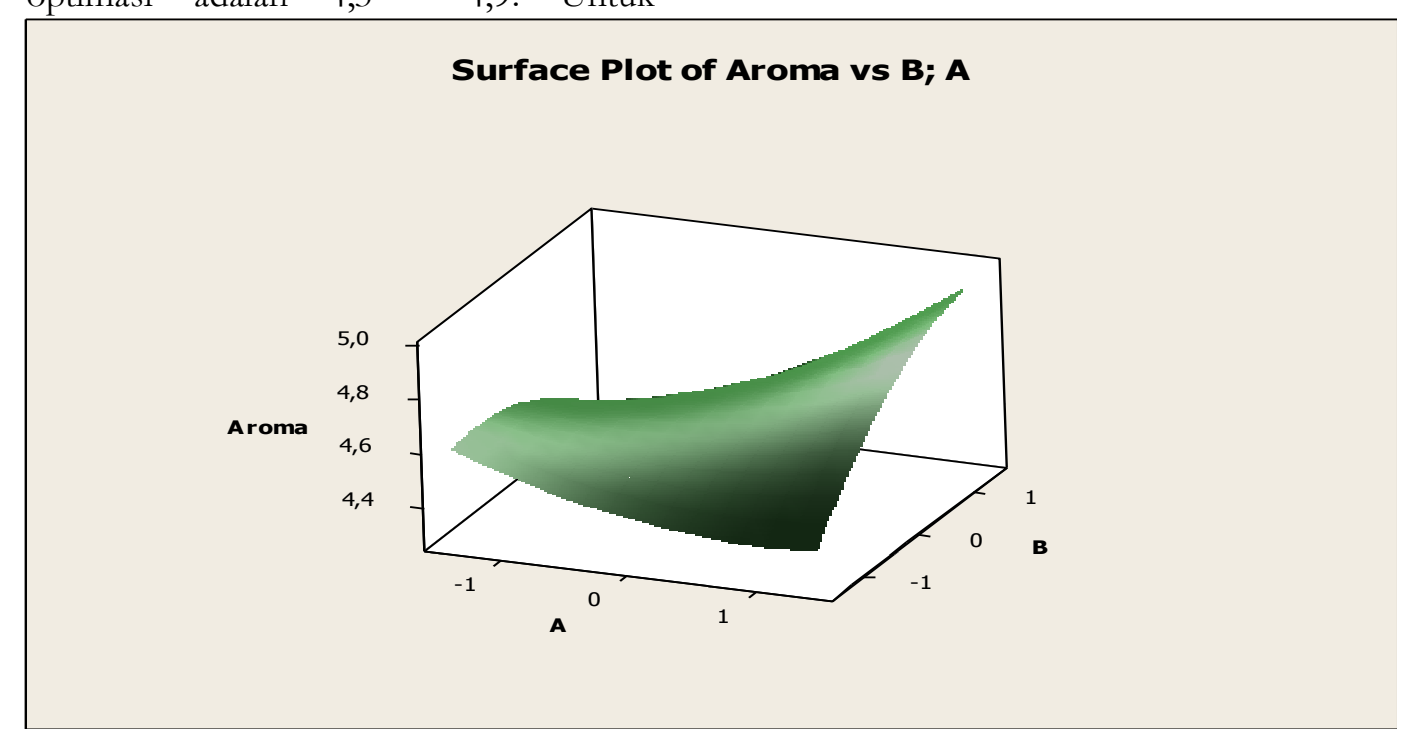

Gambar 8. Surface Plot Wilayah Optimasi dari Aroma

Dari gambar 8 Surface Plot Wilayah Optimasi, akan didapatkan penentuan wilayah optimasi berdasarkan nilai rata-rata sampel. Untuk batasan wilayahnya dapat dilihat pada tabel 4.5 Penelitian ini didasarkan pada pengujian 4 formulasi berbeda yang disajikan kepada 26 panelis. Setelah dilakukan uji organoleptik terhadap parameter warna, didapatkan hasil data penelitian yang disajikan pada tabel 4 :

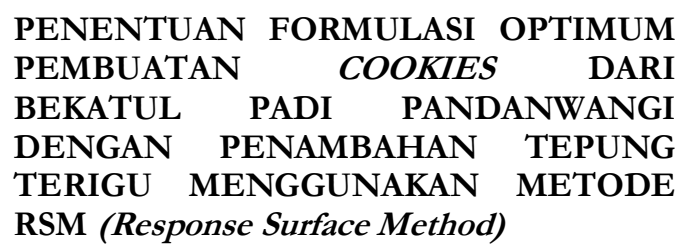

RIZA TRIHADITIA, MELISSA SYAMSIAH dan ALIYA AWALIYAH 
Tabel 4 Wilayah Optimasi Rata-rata Aroma

\begin{tabular}{cc}
\hline Wilayah Optimasi & Rata-rata Aroma \\
\hline 1 & $>4,9$ \\
2 & $4,8-4,9$ \\
3 & $4,7-4,8$ \\
4 & $4,6-4,7$ \\
5 & $4,5-4,6$ \\
6 & $4,4-4,5$ \\
7 & $4,3-4,4$ \\
8 & $<4,3$ \\
\hline
\end{tabular}

Sumber : Data primer (olahan) tahun 2018 .

Untuk mendapatkan nilai optimal dari berbagai jenis sampel yang digunakan, maka nilai rata-rata sampel tersebut akan dimasukan ke dalam plot wilayah optimasi, sehingga akan didapatkan nilai optimasi dari berbagai sampel tersebut, dapat dilihat pada tabel 5 :

Tabel 5 Nilai Optimasi Rata-Rata Aroma

\begin{tabular}{ccc}
\hline \multicolumn{1}{c}{ Sampel } & Rata-rata & Wilayah Optimasi \\
\hline F1 (BK 70\% : TT 30\%) & 4,58 & 5 \\
\hline F2 (BK 60\% : TT 40\%) & 4,54 & 5 \\
\hline F3 (BK 50\%: TT 50\%) & 4,38 & 7 \\
\hline F4 (BK 40\%: T' 60\%) & 4,77 & 3 \\
\hline
\end{tabular}

Sumber : Data primer (olahan) tahun 2018.

*Keterangan : BK (Bekatul) T'T (Tepung Terigu)

Dari tabel 5 dapat diketahui bahwa F3 (BK 50\% : T'T 50\%) mempunyai nilai optimasi 7 , dikarenakan rata-rata sampel tersebut berada diwilayah dengan nilai optimasi 6. Sampel F2 (BK 60\% : TT 40\%) serta F1 (BK 70\% : TT $30 \%$ mempunyai nilai optimasi 5, dikarenakan rata-rata sampel tersebut berada di wilayah dengan nilai optimasi 5 . Sampel F4 (BK 40\% : T'T 60\%) mempunyai nilai optimasi 3, dikarenakan rata-rata sampel tersebut berada diwilayah dengan nilai optimal 3.

Sampel terbaik untuk nilai optimasi aroma adalah sampel F4 (BK 40\% : TT 60\%) dikarenakan sampel tersebut mempunyai nilai optimasi 3. Nilai tersebut didapat karena diduga panelis tidak terlalu menyukai aroma dari bekatul itu sendiri, wangi bekatul masih asing untuk para panelis karena rata-rata panelis belum pernah mencoba olahan dari bekatul sendiri.

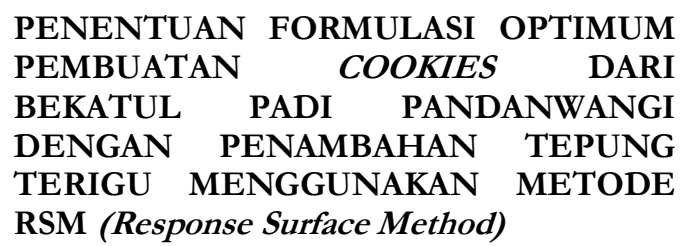

Menurut Winarno (2002) mengatakan bahwa pada umumnya terdapat empat bau utama yaitu harum, asam, tengik dan hangus merupakan yang diterima oleh hidung dan otak lebih banyak dari berbagai campuran.

Bekatul yang dapat terjadi perubahan bekatul mudah rusak, kurang tahan lama, cepat berbau dan menjadi tengik. merupakan karena adanya kandungan lemak yang relatif tinggi. Menurut Janathan (2007) mengatakan bahwa terjadi akibat lipase yang menghidrolisis lemak menjadi asam lemak dan gliserol adalah ketidakstabilan pada bekatul. Asam lemak bebas dioksidasi oleh enzim lipoksigenase menjadi bentuk peroksida, keton, aldehid, sehingga bekatul menjadi tengik.

Penerimaan panelis terhadap aroma cookies juga berbeda-beda disebabkan rangsangan terhadap aroma yang berbeda, sehingga hasil penilaian yang diberikan juga sangat relatif. Hasil

RIZA TRIHADITIA, MELISSA SYAMSIAH dan ALIYA AWALIYAH 
dari penilaian yang dapat diketahui bahwa semakin kecil presentasi penambahan bekatul maka nilai yang diberikan semakin tinggi. Pada sampel F4, diduga dikarenakan bekatul yang ditambahkan pada cookies tersebut paling sedikit dibanding sampel lain yaitu 40\% sehingga panelis lebih menyukai sampel F4.

\section{Tekstur}

Pelakukan Perhitungan Central Composite Design didapatkan hasil :

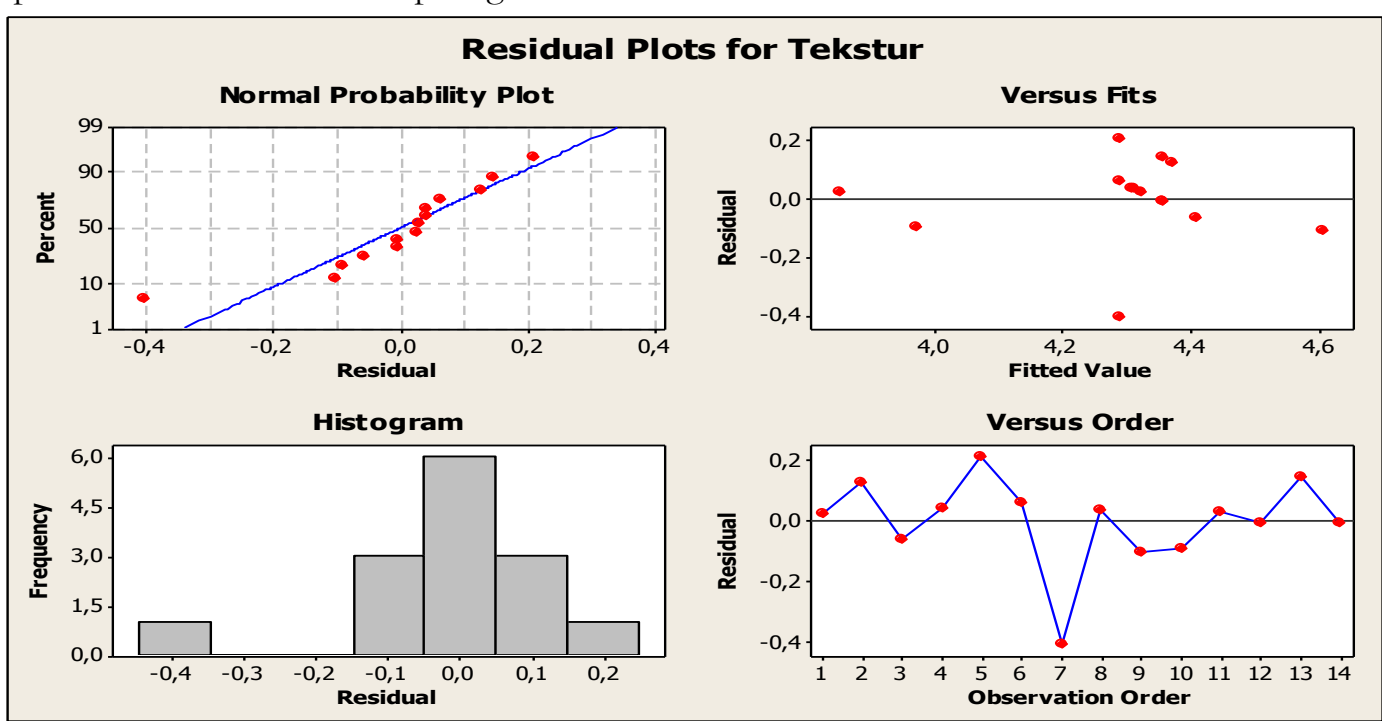

Gambar 9 Grafik Perhitungan ANOVA dari Parameter Tekstur

Berdasarkan pada gambar 9, dapat diketahui bahwa sebaran data untuk tekstur tersebar rata, serta mempunyai normal probability yang baik, dimana titiktitik data tersebut mendekati ke garis normal probability. Dikarenakan data tersebut normal dan sebarannya merata, untuk itu data-data tersebut dapat dilakukan perhitungan selanjutnya.

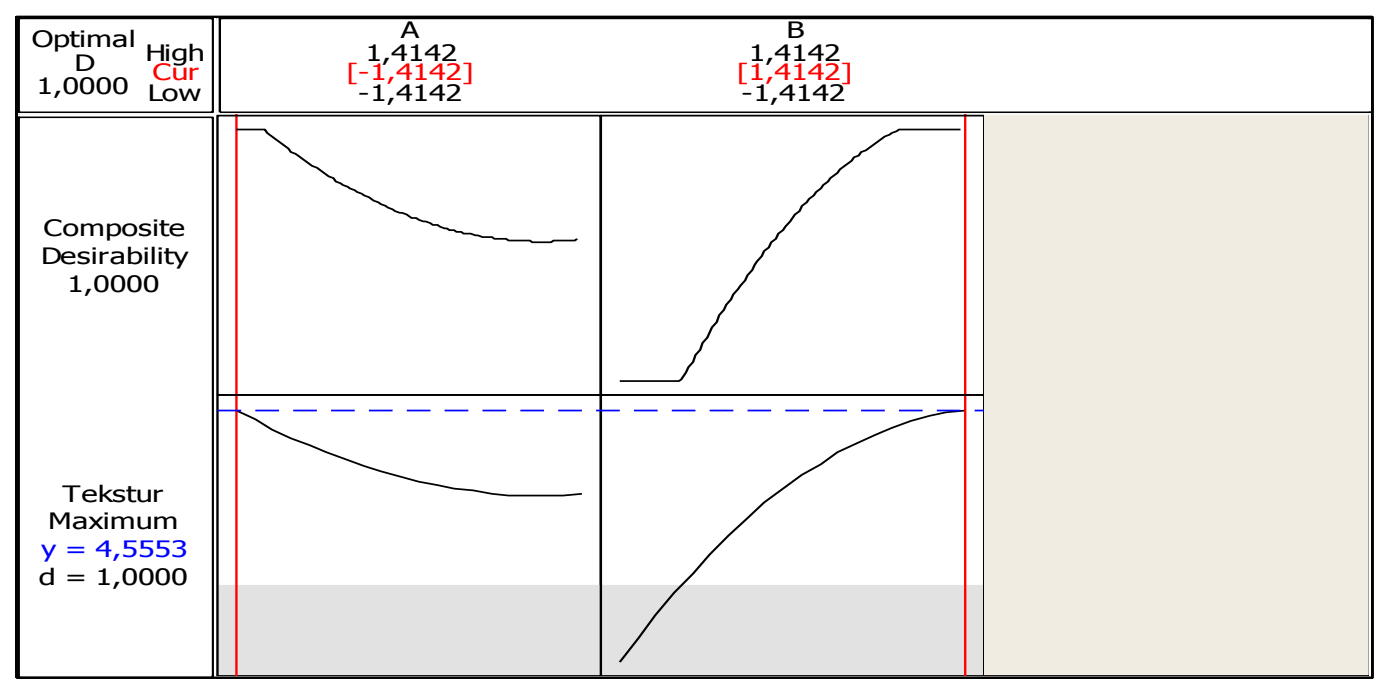

Gambar 10. Nilai Optimasi dari Parameter Tekstur

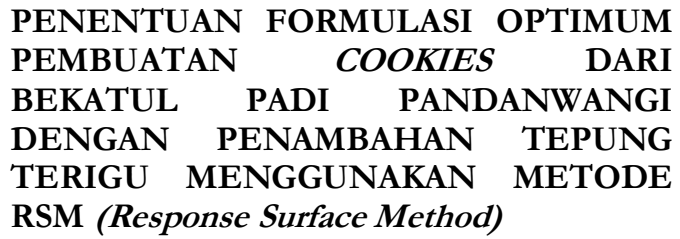

PENENTUAN FORMULASI OPTIMUM PEMBUATAN COOKIES DARI BEKATUL PADI PANDANWANGI DENGAN PENAMBAHAN TEPUNG TERIGU MENGGUNAKAN METODE RSM (Response Surface Method)

RIZA TRIHADITIA, MELISSA SYAMSIAH dan ALIYA AWALIYAH 
Pada gambar 10 perhitungan untuk optimasi akan didapatkan bahwa nilai tekstur akan optimal pada nilai 4,5553. Dimana akan membentuk suatu parabola yang terbuka kebawah dan mencirikan bahwa nilai tekstur tersebut mempunyai nilai optimal. Nilai fungsi desirability menunjukan skala nilai 1,00 dimana menurut Deringer dan Suich
(2002) dalam Sunaryo (2008), skala 1.00 0.80 menunjukan angka sangat baik artinya parameter warna ideal dan bisa diterima oleh panelis. Setelah nilai optimasi dari parameter warna diketahui maka akan ditentukan daerah optimasi oleh grafik secara contour dan surface, lalu didapatkan hasil sebagai berikut :

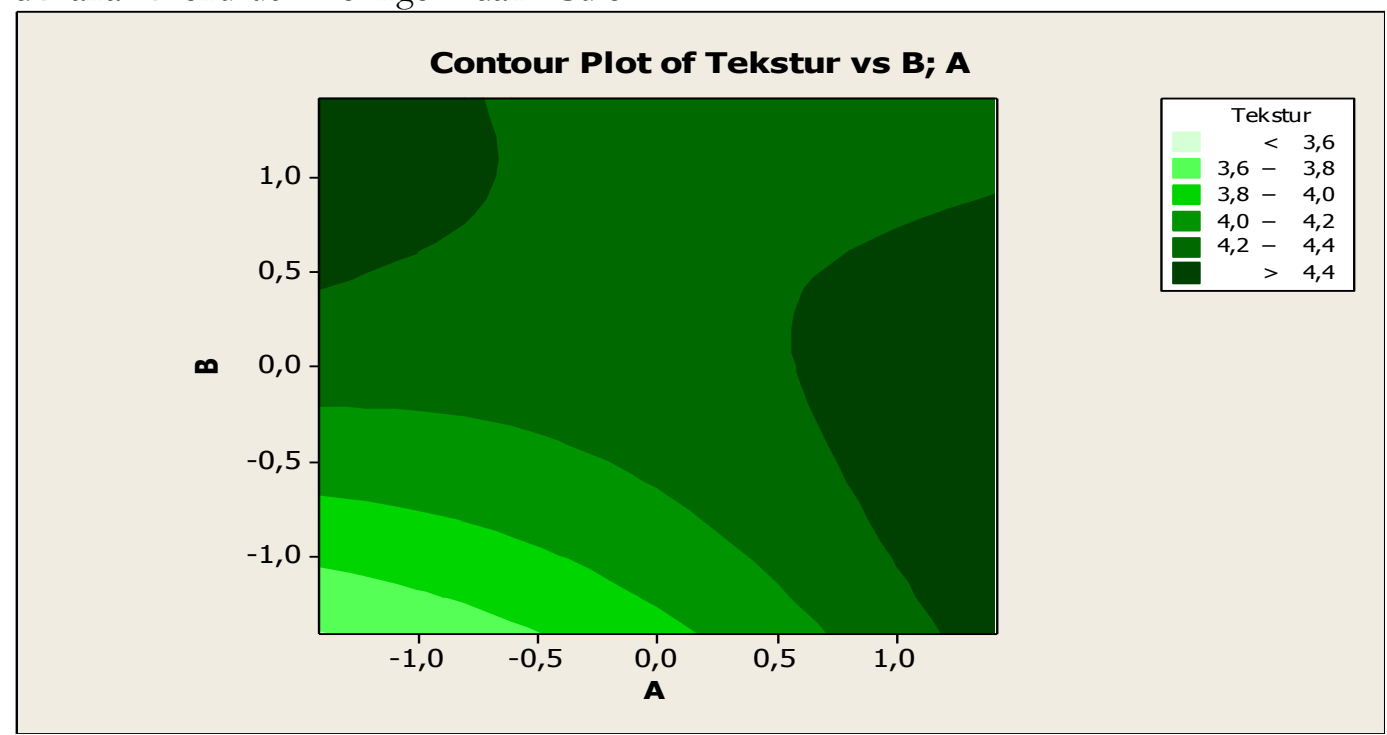

Gambar 11 Contour Wilayah Optimasi dari Tekstur

Dari gambar 11 dapat diketahui bahwa batasan wilayah untuk nilai optimasi adalah diantara 3,6 - 4,4. Penentuan wilayah optimasi tersebut dapat direpresentasikan dengan bentuk 3D. Bisa dilihat pada gambar

12.

\section{Surface Plot of Tekstur vs B; A}

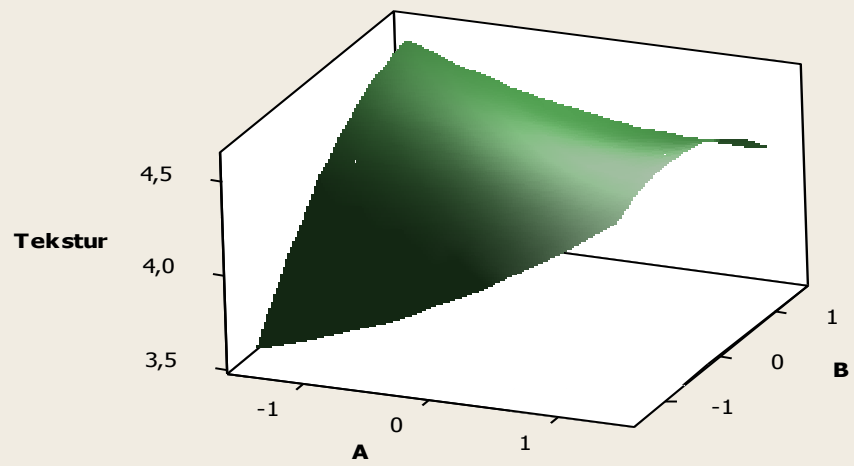

Gambar 12 Surface Plot Wilayah Optimasi Tekstur

\section{PENENTUAN FORMULASI OPTIMUM \\ PEMBUATAN COOKIES DARI \\ BEKATUL PADI PANDANWANGI \\ DENGAN PENAMBAHAN TEPUNG \\ TERIGU MENGGUNAKAN METODE \\ RSM (Response Surface Method)}

RIZA TRIHADITIA, MELISSA SYAMSIAH dan ALIYA AWALIYAH 
Dari gambar 12 Surface Plot wilayah optimasi, akan didapatkan penentuan wilayah optimasi berdasarkan nilai rata-rata sampel. Untuk batasan wilayahnya dapat dilihat pada tabel 5 . Penelitian ini didasarkan pada pengujian 4 formulasi yang berbeda yang disajikan kepada 26 panelis. Setelah dilakukan uji organoleptik terhadap parameter tekstur, didapatkan hasil data penelitian yang disajikan pada tabel 5 :

Tabel 5. Wilayah Optimasi Rata-rata Tekstur

\begin{tabular}{cc}
\hline Wilayah Optimasi & Rata-rataTekstur \\
\hline 1 & $>4,4$ \\
2 & $4,2-4,4$ \\
3 & $4,0-4,2$ \\
4 & $3,8-4,0$ \\
5 & $3,6-3,8$ \\
6 & $<3,6$ \\
\hline
\end{tabular}

Sumber : Data primer (olahan) tahun 2018

Untuk mendapatkan nilai optimal dari berbagai jenis sampel yang digunakan, maka nilai rata-rata sampel tersebut akan dimasukan ke dalam plot wilayah optimasi, sehingga akan didapatkan nilai optimasi dari berbagai sampel tersebut dapat dilihat pada tabel 6 :

Tabel 6. Nilai Optimasi Rata-Rata Tekstur

\begin{tabular}{ccc}
\hline Sampel & Rata-rata & Wilayah Optimasi \\
\hline F1 (BK 70\%: TT 30\%) & 3,88 & 4 \\
\hline F2 (BK 60\%: TT 40\%) & 4,50 & 1 \\
\hline F3 (BK 50\%: TT 50\%) & 4,35 & 2 \\
\hline F4 (BK 40\%: TT 60\%) & 4,35 & 2 \\
\hline
\end{tabular}

Sumber : Data primer (olahan) tahun 2018

*Keterangan : BK (Bekatul) TT (Tepung Terigu)

Pada tabel 6 diketahui bahwa sampel F1 (BK 70\% : T'T 30\%) mempunyai nilai optimasi 4 , dikarenakan nilai rata-rata sampel tersebut berada diwilayah dengan nilai optimasi 4. Sampel F3 (BK 50\% : TT 50\%) dan sampel F4 (BK 40\% : TT 60\%) mempunyai nilai optimasi 2, dikarenakan nilai rata-rata sampel tersebut berada di wilayah dengan nilai optimasi 2. Sampel F2 (BK 60\% : TT $40 \%$ mempunyai nilai optimasi 1, dikarenakan nilai rata-rata sampel tersebut berada diwilayah dengan nilai optimasi 1 . Sampel terbaik untuk nilai optimasi tekstur adalah sampel F2 (BK 60\% : TT $40 \%$, dikarenakan sampel tersebut mempunyai nilai optimasi 1 , dan berada

\footnotetext{
PENENTUAN FORMULASI OPTIMUM

PEMBUATAN COOKIES DARI

BEKATUL PADI PANDANWANGI

DENGAN PENAMBAHAN TEPUNG

TERIGU MENGGUNAKAN METODE

RSM (Response Surface Method)
}

diwilayah puncak dari kubah nilai optimasi.

Bekatul mengandung karbohidrat, protein, mineral, lemak, multi vitamin $\mathrm{B}$ (B1, B2, B3, B5, B6, dan B15), komponen-komponen bioaktif termasuk nitrilosid (zat yang sekarang sedang diperbincangkan sebagai zat antikanker), dan dietary fiber (serat pencernaan) (Ardiansyah, 2004). Kandungan serat kasar yang tinggi pada bekatul menyebabkan tekstur bekatul setelah mengalami proses pemanasan menjadi renyah, karena sifat bekatul yang sulit untuk diikat dengan komposisi bahan lain sehingga bekatul yang telah melalui proses pemanasan membentuk pori-pori atau

RIZA TRIHADITIA, MELISSA SYAMSIAH dan ALIYA AWALIYAH 
rongga-rongga kecil sehingga cookies tersebut menjadi renyah.

\section{Rasa}

Rasa adalah faktor yang sangat penting dalam menentukan penerimaan panelis terhadap produk yang dihasilkan. Ada empat rasa yang dikenal yaitu rasa manis, asin, asam dan pahit (Soekarto, 1985 dalam Trihaditia, 2015).
Cita rasa flavour yang dapat memberikan rangsangan pada indera penerima pada saat mengecap dan kesan yang ditinggalkan pada indera perasa setelah seseorang menelan produk tersebut (Winarno, 2002).

Melakukan perhitungan central composite design sebagai berikut :

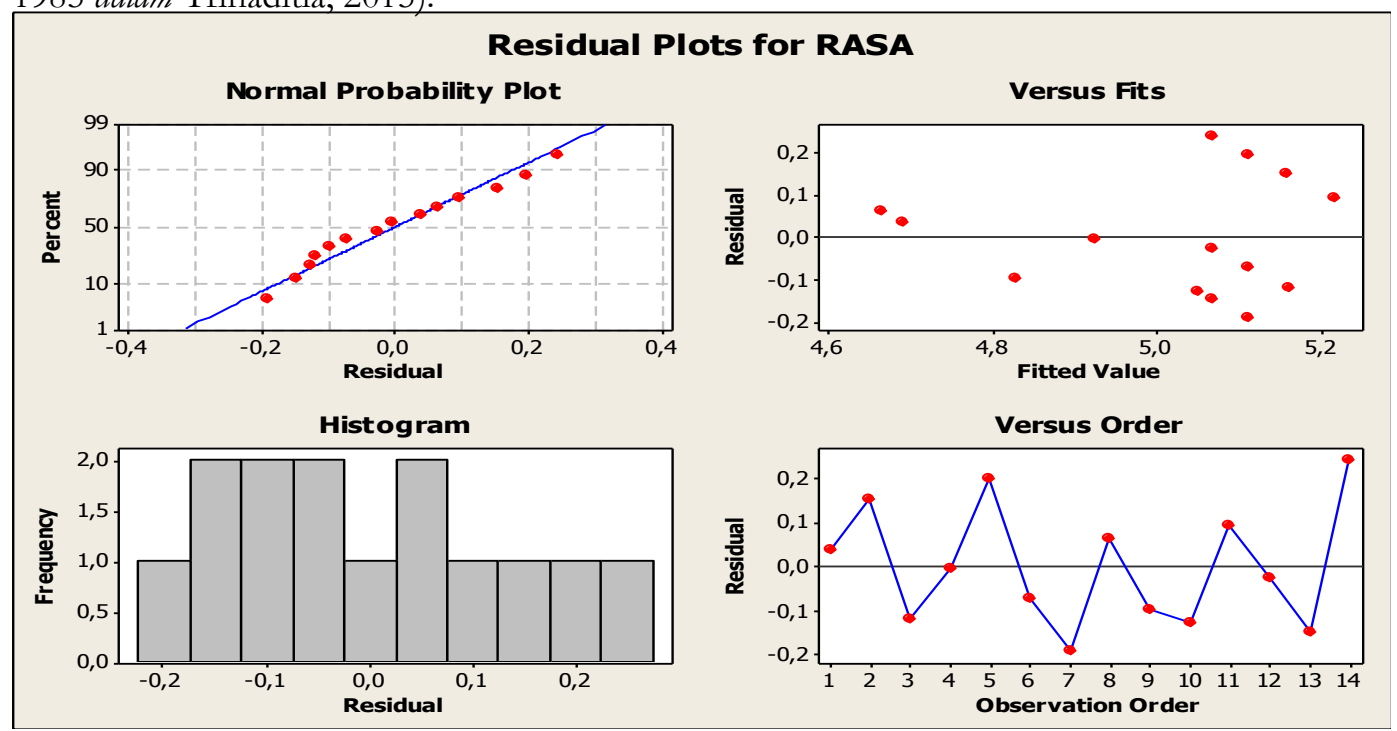

Gambar 13 Grafik Perhitungan ANOVA dari Parameter Rasa

Berdasarkan pada gambar 13, dapat diketahui bahwa sebaran data untuk rasa tersebar rata, serta mempunyai normal probability yang baik, dimana titik-titik data

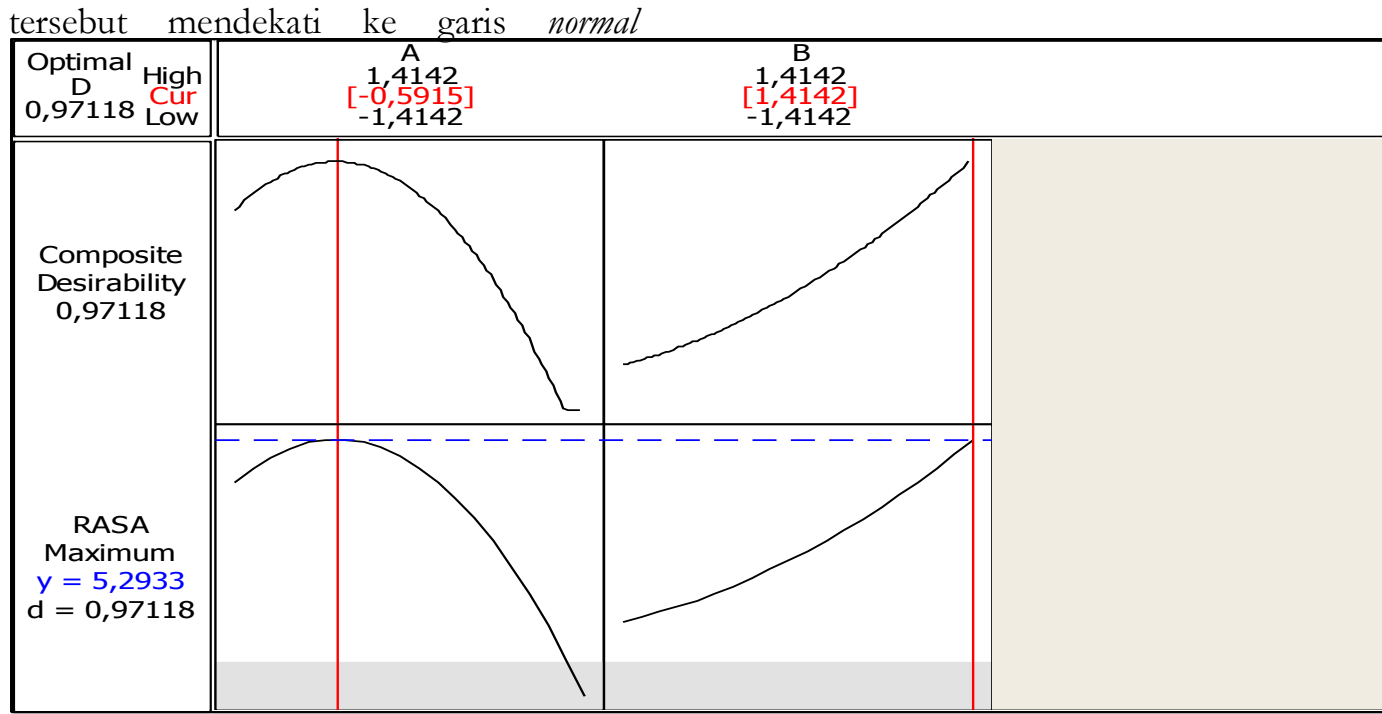

Gambar 14 Nilai Optimasi dari Parameter Rasa

PENENTUAN FORMULASI OPTIMUM

PEMBUATAN COOKIES DARI

BEKATUL PADI PANDANWANGI

DENGAN PENAMBAHAN TEPUNG

TERIGU MENGGUNAKAN METODE

RSM (Response Surface Method) probability. Dikarenakan data tersebut normal dan sebarannya merata, untuk itu data-data tersebut dapat dilakukan perhitungan selanjutnya.
RIZA TRIHADITIA, MELISSA SYAMSIAH dan ALIYA AWALIYAH 
Pada gambar 14 perhitungan untuk optimasi akan didapatkan bahwa nilai rasa akan optimal pada nilai 5,2933. Dimana akan membentuk suatu parabola yang terbuka kebawah dan mencirikan bahwa nilai tekstur tersebut mempunyai nilai optimal.

$\begin{array}{crrr}\text { Nilai } & \text { fungsi } & \text { desirability } \\ \text { menunjukan skala nilai } & 0,97 & \text { dimana }\end{array}$

menurut Deringer dan Suich (2002) dalam Sunaryo (2008), skala 1.00 - 0.80 menunjukan angka sangat baik artinya parameter warna ideal dan bisa diterima oleh panelis. Setelah nilai optimasi dari parameter warna diketahui maka akan ditentukan daerah optimasi oleh grafik secara contour dan surface, lalu didapatkan hasil sebagai berikut :
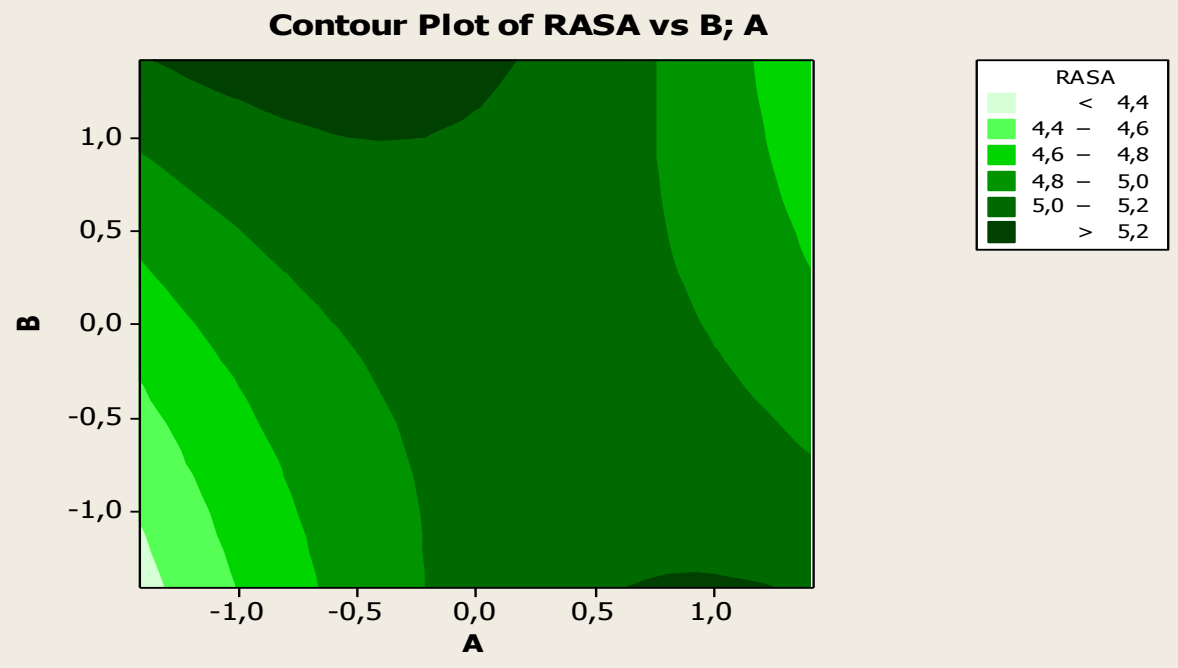

Gambar 15 Contour Wilayah Optimasi dari Rasa

Dari gambar 15 dapat diketahui bahwa batasan wilayah untuk nilai optimasi adalah diantara 4,4 - 5,2. Penentuan wilayah optimasi tersebut dapat direpresentasikan dengan bentuk 3D. Bisa dilihat pada gambar 16 .

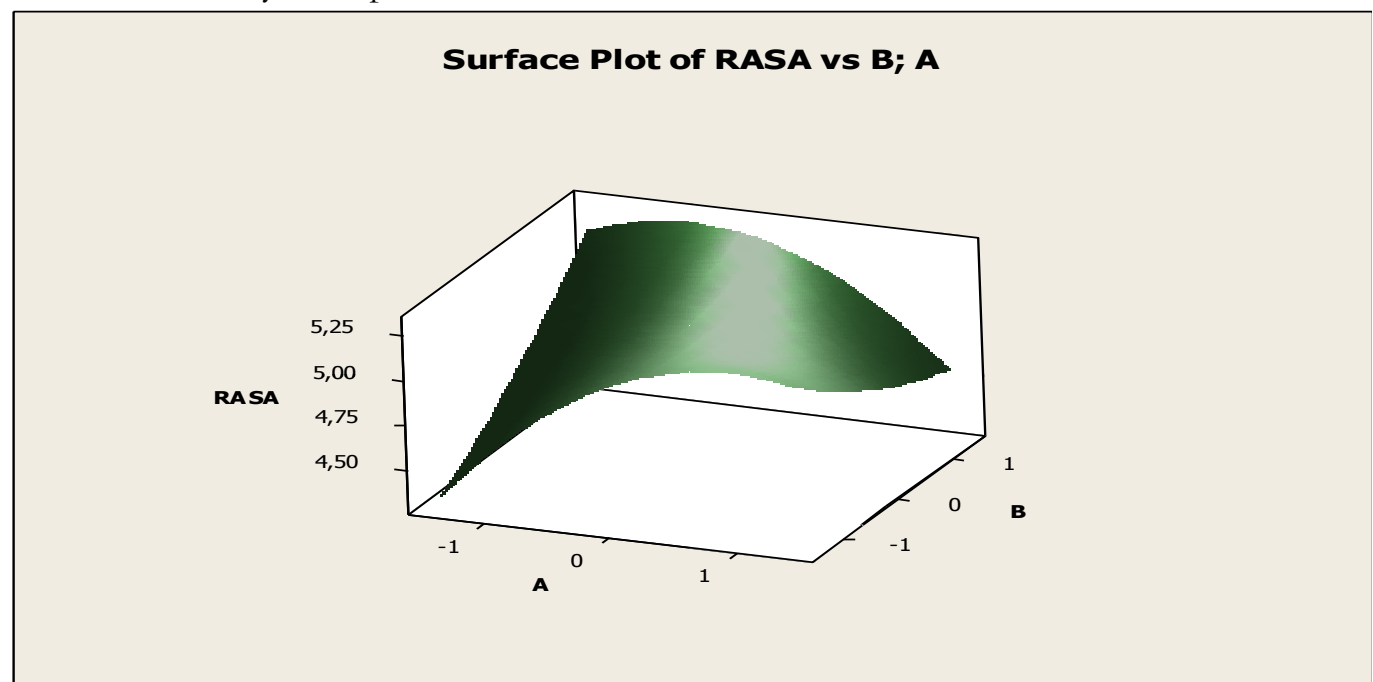

Gambar 16 Surface Plot Wilayah Optimasi Rasa

PENENTUAN FORMULASI OPTIMUM

PEMBUATAN COOKIES DARI

RIZA TRIHADITIA, MELISSA SYAMSIAH dan ALIYA

BEKATUL

PADI PANDANWANGI AWALIYAH 
Dari gambar 16 Surface Plot wilayah optimasi, akan didapatkan penentuan wilayah optimasi berdasarkan nilai rata-rata sampel. Untuk batasan wilayahnya dapat dilihat pada tabel 7 . Penelitian ini didasarkan pada pengujian 4 formulasi yang berbeda yang disajikan kepada 26 panelis. Setelah dilakukan uji organoleptik terhadap parameter rasa, didapatkan hasil data penelitian yang disajikan pada tabel 7 :

Tabel 7 Wilayah Optimasi Rata-rata Rasa

\begin{tabular}{cc}
\hline Wilayah Optimasi & Rata-rata Rasa \\
\hline 1 & $>5,2$ \\
2 & $5,0-5,2$ \\
3 & $4,8-5,0$ \\
4 & $4,6-4,8$ \\
5 & $4,4-4,6$ \\
6 & $<4,4$ \\
\hline
\end{tabular}

Sumber : Data primer (olahan) tahun 2018

Untuk mendapatkan nilai optimal dari berbagai jenis sampel yang digunakan, maka nilai rata-rata sampel tersebut akan dimasukan ke dalam plot wilayah optimasi, sehingga akan didapatkan nilai optimasi dari berbagai sampel tersebut dapat dilihat pada tabel 8 :

Tabel 8 Nilai Optimasi Rata-Rata Rasa

\begin{tabular}{ccc}
\hline Sampel & Rata-rata & Wilayah Optimasi \\
\hline F1 (BK 70\%: TT 30\%) & 4,73 & 4 \\
\hline F2 (BK 60\%: TT 40\%) & 5,31 & 1 \\
\hline F3 (BK 50\%: TT 50\%) & 5,04 & 2 \\
\hline F4 (BK 40\%: TT 60\%) & 4,92 & 3 \\
\hline
\end{tabular}

Sumber : Data primer (olahan) tahun 2018

*Keterangan : BK (Bekatul) TT (Tepung Terigu)

Pada tabel 8 diketahui bahwa sampel dengan F1 (BK 70\% : TT 30\%) mempunyai nilai optimasi 4 , dikarenakan rata-rata sampel tersebut berada diwilayah dengan nilai optimasi 4. F4 (BK 40\% : TT $60 \%$ mempunyai nilai optimasi 3 , dikarenakan rata-rata sampel tersebut berada diwilayah dengan nilai optimasi 3 . F3 (BK 50\%: TT 50\%) mempunyai nilai optimasi 2, dikarenakan rata-rata sampel tersebut berada diwilayah dengan nilai optimasi 2. F2 (BK 60\% : TT 40\%) mempunyai nilai optimasi 1 , dikarenakan rata-rata sampel tersebut berada diwilayah dengan nilai optimasi 1 . Sampel terbaik untuk nilai optimasi rasa adalah sampel F2 (BK 60\% : TT 40\%) dikarenakan sampel tersebut memiliki nilai optimasi 1 , dan

PENENTUAN FORMULASI OPTIMUM PEMBUATAN COOKIES DARI BEKATUL PADI PANDANWANGI DENGAN PENAMBAHAN TEPUNG TERIGU MENGGUNAKAN METODE RSM (Response Surface Method) berada diwilayah teratas kubah nilai optimasi.

Rasa cookies dipengaruhi oleh komponen penyusunnya terutama dari sukrosa, lemak dan asam amino. Secara umum, rasa manis cookies berasal dari sukrosa dan laktosa, sedangkan protein dan lemak memberikan rasa gurih (Masuda et al., 2005).

Pada penilaian optimasi rasa ternyata panelis menyukai penambahan bekatul yang lebih banyak dibanding dengan sampel lain, yaitu penambahan bekatul pada sampel F2 sebanyak 60\%. Meskipun bekatul merupakan bahan pangan yang belum dikenal oleh panelis, tetapi penilaian rasa terhadap cookies bekatul cukup baik.

RIZA TRIHADITIA, MELISSA SYAMSIAH dan ALIYA AWALIYAH 
Penentuan Sampel Terbaik

Tabel 9 Penentuan Sampel Terbaik

\begin{tabular}{ccccccccc}
\hline \multirow{2}{*}{ Sampel } & \multicolumn{2}{c}{ Warna } & \multicolumn{2}{c}{ Aroma } & \multicolumn{2}{c}{ Tekstur } & \multicolumn{2}{c}{ Rasa } \\
\cline { 2 - 9 } & Rata-rata & Optimasi & Rata-rata & Optimasi & Rata-rata & Optimasi & Rata-rata & Optimasi \\
\hline F1 & 3,61 & $\mathbf{5}$ & 4,58 & $\mathbf{5}$ & 3,88 & 4 & 4,73 & 4 \\
F2 & 4,35 & 2 & 4,54 & $\mathbf{5}$ & 4,50 & 1 & $\mathbf{5 , 3 1}$ & 1 \\
F3 & 4,27 & 2 & 4,38 & 7 & 4,35 & 2 & $\mathbf{5 , 0 4}$ & $\mathbf{2}$ \\
F4 & 4,50 & 1 & 4,77 & 3 & 4,35 & 2 & 4,92 & 3 \\
\hline
\end{tabular}

Sumber : Data primer (olahan) tahun 2018

\section{Keterangan :}

$\mathrm{F} 1=$ Bekatul 70\% + Tepung Terigu 30\%

$\mathrm{F} 2=$ Bekatul $60 \%+$ Tepung Terigu 40\%

F3 = Bekatul 50\% + Tepung Terigu 50\%

F4 $=$ Bekatul $40 \%+$ Tepung Terigu $60 \%$

Tabel 9 menunjukan nilai optimasi yang berbeda-beda dari karakteristik organoleptiknya, nilai optimasi dari berbagai sampel yang ditunjukan oleh nilai optimasi, dimana nilai optimasi tersebut menunjukan kelas pada nilai karakteristik organoleptik tersebut. Semakin kecil nilai optimasi maka akan semakin tinggi nilai yang didapat. Oleh karena itu, sampel yang mendapatkan nilai yang tinggi adalah sampel yang lebih disukai panelis.

Pada sampel yang ditunjukan tabel 4.13 menunjukan bahwa nilai F2 (bekatul 60\% + Tepung 40\%) mendapatkan nilai optimasi rata-rata paling tinggi dari segi tekstur dan rasa, sedangkan dari segi warna dan aroma nilai optimasi yang paling tinggi adalah $\mathrm{F} 4$ (bekatul 40\% + tepung 60\%.

\section{KESIMPULAN DAN SARAN}

\section{Kesimpulan}

Pembuatan cookies berbahan dasar bekatul padi pandanwangi yang ditambahkan tepung terigu berpengaruh terhadap warna, aroma, tekstur, dan rasa. Karakteristik warna dan aroma yang diminati oleh panelis adalah sampel F4

\footnotetext{
PENENTUAN FORMULASI OPTIMUM PEMBUATAN COOKIES DARI BEKATUL PADI PANDANWANGI DENGAN PENAMBAHAN TEPUNG TERIGU MENGGUNAKAN METODE RSM (Response Surface Method)
}

(bekatul 40\% + tepung 60\%) dengan nilai optimasi warna yaitu 1 , dan nilai optimasi aroma 3. Karakteristik tekstur dan rasa yang diminati oleh panelis adalah sampel F2 (Bekatul 60\% + tepung 40\%) dengan nilai optimasi warna yaitu 1 .

Saran

Formulasi yang paling diminati adalah sampel F2 (Bekatul 60\% + tepung $40 \%$ ) dari segi tekstur, rasa, dan warna sedangkan dari segi aroma kurang diminati, maka perlu adanya penelitian lebih lanjut, dilakukan penambahan senyawa lain seperti ekstrak vanilla agar aroma wanginya lebih kuat, karena dari segi warna, tekstur dan rasa sudah dapat diterima oleh indera panelis.

\section{DAFTAR PUSTAKA}

Agustini, S., Priyanto, G., Basuni, H., Santoso, B. dan Pambayu, R. 2014. Changes on Then Physical-Chemical Properties of Kue Delapan Jam on Various Steaming Time. 7 (2) : 161165.

Ardiansyah. 2004. Sehat Dengan Mengonsumsi Bekatul. Diakses dari http://www. gizi.net pada tanggal 12 September 2017.

RIZA TRIHADITIA, MELISSA SYAMSIAH dan ALIYA AWALIYAH 
Dio. 2010. Bekatul Padi Turunkan Kadar Kolesterol. Majalah Sinar Harapan.

Fellows, P. 1990. Debydration. In Encyclopedia of Food Science and Technology. New York :Jhon Wiley and Sons, Inc.

Janathan. 2007. Karakteristik Fisikokimia Tepung Bekatul Serta Optimasi Formulasi Dan Pendugaan Umur Simpan Minuman Campuran Susu Skim Dan Tepung Bekatul. Skripsi. Fakultas Teknologi Pertanian. Institut Pertanian Bogor. Bogor.

Henderson, A.J., Ollila, C.A., Kumar, A., Borreses, E.C., Raina, K., Agarwal, R., Ryan, E.P. 2012. Chemopreventive Properties of Dietary Rice Bran: Current Status and Future Prospects. Advances in Nutrition. 3 : 643-653.

Masuda, T., Ide, N., and Kitabatake, N. 2005. Effect of Chemical Modification of Lysine Residues on The Sweetness of Lysozyme. Chemical sense: 30: 253-264.

Montgomery, D.C. 2009. Design and Analysis of Experiments. New York : John Wiley and Sons, Inc.

Rejeki, M.S.W., Astri, P., Dennis, A., Pratiwi, R.U., Ndaru, K., Dian, W., Aisyah, M. 2012. Penentuan Kualitas Pangan Dan Uji Organoleptik. Jurnal ITP Organoleptik. Universitas Diponegoro. Semarang.

Sunaryo, S. 2008. Optimasi Multi Respon dengan Pendekatan Fungsi
Desirability untuk Rancangan Gabungan Mixture Design dan Orthogonal Array dari Taguchi pada Proses Pembuatan Lem di PT XYZ, J. Ilmiah Sains dan Teknologi. (7) $2: 106-113$.

Trihaditia, R. 2015. Penentuan Formulasi Optimum pada Pembuatan Minuman Fungsional Rambut Jagung dengan Penambahan Madu dan Jeruk Nipis Menggunakan Metode RSM (Response Surface Method). Tesis. Fakultas Teknologi Pangan Universitas Pasundan. Bandung.

Wahyuningtyas, D. 2010. Uji Organoleptik Hasil jadi Kue Menggunakan Bahan Non Instant dan Instant. Jakarta Barat:Universitas Bina Nusantara.

Watts, B.M., Ylimaki, G.L., Jefry, L.E. and Elins, L.G. 1993. Dasar-Dasar Metode Sensori untuk Evaluasi Pangan, terjemahan oleh Purwadi. Fakultas Peternakan. Universitas Brawijaya. Malang.

Winarno, F.G. 1992. Kimia Pangan dan Gizi. Jakarta:PT. Gramedia Pustaka Utama.

Yuniarrahmani, C. 2001. Pengawetan Bekatul dengan Perlakuan Fisik : Pemanasan Menggunakan Drum Drier, Ekstruder, Penyangraian, Pengukusan dan Autoclave. Skripsi. Fakultas Teknologi Pertanian Institut Pertanian Bogor. Bogor.

\footnotetext{
PENENTUAN FORMULASI OPTIMUM PEMBUATAN COOKIES DARI BEKATUL PADI PANDANWANGI DENGAN PENAMBAHAN TEPUNG TERIGU MENGGUNAKAN METODE RSM (Response Surface Method)
}

RIZA TRIHADITIA, MELISSA SYAMSIAH dan ALIYA AWALIYAH 